\title{
The Application of Tetragon Analysis in A Sample of Kurdish Adult Population with Class I Occlusion:A Cephalometric Study

\author{
Shaho Ziyad Jamil Al-Talabani $(\mathrm{PhD})^{1}$ \\ ${ }^{1}$ College of Dentistry, Hawler Medical University, Erbil , Iraq \\ email: shaho.talabani@hmu.edu.krd mobile 009647504556685
}

Received: 13 December 2020

Revised: 28 December 2020

Accepted: 24 January 2021

Published: 15 April 2021

Diyala Medical Journal 2021:20(1): 22-33

\section{Abstract}

Background: Visual cephalometric analysis is a simple, logical, and accurate diagnostic tool for the student, the clinician, and the researcher. The analysis is elicited from two geometric constructs, the Tetragon and the Trigon.

Objective: To determine the cephalometric norms as per Fastlicht's analysis for male and female subjects of the Kurdish population and to compare these cephalometric norms with Fastlicht's norms, average Caucasian norms, and Iraqi (non-Kurdish) norms.

Patients and Methods: The cephalometric radiographs of 63 individuals, 25males, mean age $23.01 \pm 2.9$ years, and 38 females, mean age $23 \pm 3.2$ years, were selected. FACAD 3.4.0.3, an orthodontic tracing software for cephalometric analysis and treatment planning, was used to digitally trace the reference points and reference lines for the tetragon analysis.

Results: The statistical differences between the data of the Iraqi Kurdish population and the data of Fastlich, average Caucasian, and Iraqi non-Kurdish population were significant. Conclusion: The data of the Kurdish population is different from that of Fastlich and nonKurdish Iraqi data. It is recommended to use this study's findings to get a more accurate result for the Iraqi Kurdish population when using tetragon analysis.

Keywords: Tetragon Analysis; Cephalometric; Visual cephalometric analysis

\section{Introduction}

Originally cephalometry was used as a method for researching craniofacial growth and development. It is gradually applied to study the facial form and develop criteria to describe orthodontic treatment objectives [1]. Moreover, recently it was used to assess the progress of treatment and predict growth for individual patients. It is worth mentioning that the emerging data that was concluded from different cephalometric analyses of Caucasian norms were incomparable with other racial and ethnic backgrounds [2,3]. Many researchers reported the variation in craniofacial morphology in various ethnic 
groups. They revealed that one group's average measurements do not necessarily represent the norm for other ethnic groups [47]. It is essential to compare each individual's cephalometric data with standards applicable to his / her ethnic background for an accurate diagnostic evaluation to achieve the favored treatment outcomes [8]. Visual cephalometric analysis is a simple, logical, and accurate diagnostic tool for the student, the clinician, and the researcher [9]. The analysis is elicited from two geometric constructs. Firstly, the "Tetragon" a polygon representing the maxillo-dento-mandibular complex, made up of reliable and familiar cephalometric landmarks the palatal plane, the mandibular plane, and the axes of the maxillary and mandibular central incisors Figure (1A). Secondly, the "Trigon," a complementary triangle situated above the Tetragon and formed by one plane that is intrinsic to the Tetragon-the palatal plane (PNS-ANS) and other two extrinsic planes -the pterygoorbital plane (Pt-Or) and the pterygopalatal plane (Pt-PNS) Figure (1B)[9]. This research's objectives were to set the normal values of visual cephalometric analysis ( the Tetragon) in the Kurdish population with average class I occlusion, examine the gender variations if any, and compare Iraqi Kurdish data with other data.

\section{Patients and Methods}

In this study, a total of 63 digitally taken lateral cephalometric radiographs belong to 25 males, mean age $23.01 \pm 2.9$ years, and 38 females, mean age $23 \pm 3.2$ years, were included. These radiographs were collected archive of faculty of dentistry,Tishk International University, Erbil, Iraq. The following selection criteria were applied:
1.The molar, Canine, and Incisor were in class I relationship

2.The overjet and the overbite were within the normal range

3.The maxillary and mandibular dental arches were well-aligned with a range of 1-2 mm dental crowding

4.No history of either orthodontic, or prosthodontic treatment and facial trauma/surgery were recorded

Each lateral cephalogram was recorded while the head was in a natural head position using the NewTom GiANO digital X-ray unit. FACAD 3.4.0.3, an orthodontic tracing software for cephalometric analysis and treatment planning, was used to digitally trace the reference points and reference lines for the tetragon analysis.

\section{Cephalometric landmarks}

For this study, the implemented cephalometric reference points were identified according to Rakosi [10]:

1.Pterygomaxillary fissure $(\mathrm{Pt})$

2.Nasion $(\mathrm{N})$

3.Sella turcica $(\mathrm{S})$

4.Point A (Subnasale)

5.Point B (Supramentale)

6.Pogonion (Pog)

7.Gonion (Go)

8.Menton (Me)

9.Anterior nasal spine (ANS)

10.Posterior nasal spine (PNS)

11.Orbitale (Or)

12. Root apices and incisal edges of the most proclined maxillary and mandibular central incisors.

\section{Linear measurements}

1.(N-Pog-UI): Distance from the incisal edge of the maxillary central incisor (UI) to $\mathrm{N}$ Pog line 
2.(N-Pog-LI): Distance from incisor edge of mandibular central incisor (LI) to N-Pog line

3.(UI-PP): Long axis of upper incisor to the palate

4.(LI-MP): Long axis of lower incisor to mandibular plane

\section{Angular measurements}

The Tetragon is composed of four sides that creates four angles with a total of $360^{\circ}$ constantly as per Faslicht [9] Figure (1A).

1.UI-PP: The angle is formed by the palatal plane's intersection with a line passing through the incisal edge and the apex root of the maxillary central incisor.

2.UI-LI: The angle is established by passing a line through the incisal edge and the apex

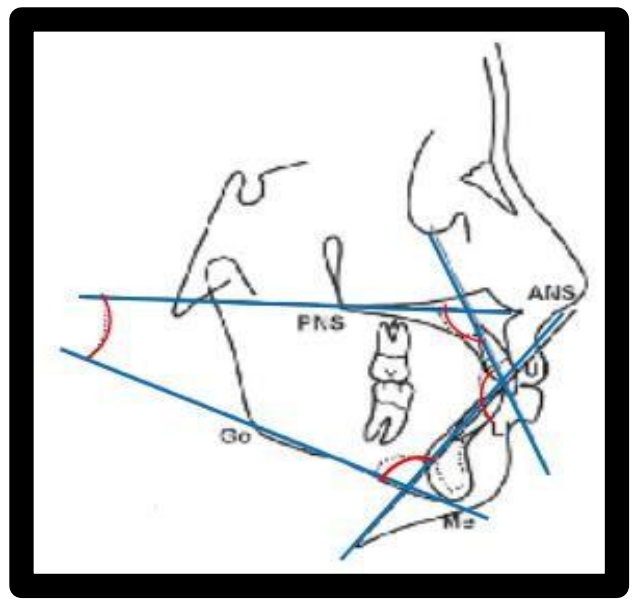

Figure(1A): First geometric

\section{Method error}

Ten random samples were selected and retraced by another examiner and by the same operator after two weeks. Intraclass Correlation Coefficient (ICC) was used to test operators' inter-examiner and intraexaminer reliability, where the ICC ranges from 0 to 1 , with 1 indicating perfect root of the maxillary and mandibular central incisors.

3.LI-MP: The angle is formed by the mandibular plane's intersection with a line passing through the incisal edge and the apex root of the mandibular central incisor.

4.MP-PP: the angle is constructed between the mandibular plane and palatal plane.

5.Others: SNA, SNB, and ANB. The Triagon consists of three sides that creates three angles with a total of $180^{\circ}$ constantly as per Faslicht (9) (Figure 1B).

6.Pt-Or/Pt-PNS: The angle between the PtOr plane and Pt-PNS plane called "upper Pt." 7.Pt-PNS/PP: The angle between the Pt-PNS and the palatal plane called "lower Pt."

8.Pt-Or/PP: The angle between the Pt-Or plane and the palatal plane.

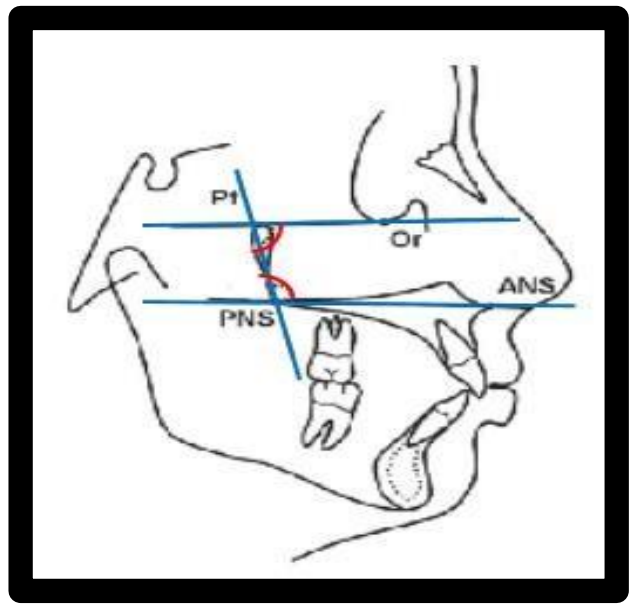

Figure (1B): Second geometric agreement. Intra-class correlation (ICC) results for both intra-examiner measurements showed high levels of agreement (>0.9).

\section{Statistical analysis}

Statistical Package for Social Science (Version 25; SPSS Inc., Chicago, IL, USA) was used to perform statistical analyses. Measurements were described as frequencies, 
means, standard deviations (SD), and minimum and maximum values were calculated for each variable. The Shapiro Wilks test assessed the normal distribution fitness of the variables, and the data were found to be fit to normal distribution. To compare the data with norms from Fastlicht's average, Caucasian, and non-Kurdish Iraq and to compare male and female data, one sample $t$ test and an independent $t$ test were used, respectively.

A p-value cutoff was applied to estimate the levels of significance, as following: Nonsignificant NS P $>0.05$, Significant $* 0.05 \geq$
$\mathrm{P}>0.01$, Highly-significant $* * 0.01 \geq \mathrm{P}>$ 0.001 , and Very highly significant $* * * \mathrm{P} \leq$ 0.001 .

\section{Results}

The values for the cephalometric parameters are described in Table (1). Table (2) compares cephalometric values between the Iraqi Kurdish sample and Fastlicht's data using a one-sample t-test. Significant differences were found between the Iraqi Kurdish and the Fastlicht's data in 10 of the 14 total parameters. The differences were found to be highly significant, $\mathrm{P}<0.001$.

Table (1): Descriptive statistics for the cephalometric variables

\begin{tabular}{|c|c|c|c|c|c|c|c|}
\hline & & Variable & $\mathrm{N}$ & Minimum & Maximum & Mean & $\begin{array}{l}\text { Standard } \\
\text { deviation }\end{array}$ \\
\hline \multirow{4}{*}{\multicolumn{2}{|c|}{$\begin{array}{l}\text { Linear } \\
\text { measurements } \\
(\mathrm{mm})\end{array}$}} & N-Pog-LI & 63 & -7.30 & 3.70 & -1.837 & 2.416 \\
\hline & & N-Pog-UI & 63 & -0.50 & 8.80 & 4.729 & 2.149 \\
\hline & & UII-PP & 63 & 17.60 & 34.20 & 27.522 & 2.954 \\
\hline & & LI-MP & 63 & 33.90 & 48.10 & 40.243 & 3.195 \\
\hline \multirow{10}{*}{ 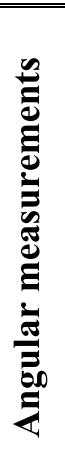 } & \multirow{4}{*}{ Tetragon } & " UI-PP & (263 & 97.80 & 130.90 & 115.676 & "5.293 \\
\hline & & UI-LI & 63 & 115.90 & 138.40 & 126.168 & 4.219 \\
\hline & & LI-MP & 63 & 86.70 & 99.80 & 92.070 & 3.649 \\
\hline & & MP-PP & 63 & 19.40 & 34.30 & 25.692 & 3.225 \\
\hline & \multirow{3}{*}{ Trigon } & UpperPt & 63 & 74.40 & 87.20 & 78.643 & 2.979 \\
\hline & & LowerPt & 63 & 85.40 & 100.50 & 94.811 & 3.075 \\
\hline & & Pt-Or/PP & 63 & -2.50 & 17.00 & 7.319 & 4.415 \\
\hline & \multirow[b]{3}{*}{ Others } & SNA & 63 & 74.00 & 92.00 & 82.362 & 3.966 \\
\hline & & SNB & 63 & 72.40 & 88.60 & 79.943 & 3.757 \\
\hline & & ANB & 63 & -3.00 & 7.80 & 2.414 & 2.324 \\
\hline
\end{tabular}


The Application of Tetragon Analysis in A Sample of Kurdish Adult Population with Class I Occlusion:A Cephalometric Study

Table (2): Comparison of the cephalometric variables for the Iraqi Kurdish individuals versus Fastlicht's average

\begin{tabular}{|c||c||c|c|c|c|c||}
\hline Variable & Kurdish & Fastlich & $\begin{array}{c}\text { Mean } \\
\text { difference }\end{array}$ & T-test & $\begin{array}{c}\text { Degree of } \\
\text { freedom }\end{array}$ & P-value \\
\hline \hline UI-PP & 115.67 & 110 & 5.676 & 8.511 & 62 & 0.000 \\
\hline \hline UI-LI & 126.16 & 130 & -3.832 & -7.209 & 62 & 0.000 \\
\hline \hline LI-MP & 92.06 & 90 & 2.070 & 4.502 & 62 & 0.000 \\
\hline MP-PP & 25.69 & 30 & -4.308 & -10.601 & 62 & 0.000 \\
\hline \hline Pt-Or/PtPNS & 78.64 & 85 & -6.357 & -16.938 & 62 & 0.000 \\
\hline \hline Pt-PNS/PP & 94.81 & 87 & 7.811 & 20.163 & 62 & 0.000 \\
\hline Pt-Or/PP & 7.31 & 8 & -0.681 & -1.224 & 62 & 0.225 \\
\hline \hline N-Pog-UI & 4.72 & 2 & 2.729 & 10.078 & 62 & 0.000 \\
\hline N-Pog-LI & 1.83 & 1 & -2.837 & -9.319 & 62 & 0.000 \\
\hline \hline UI-PP & 27.522 & 34 & -6.478 & -17.405 & 62 & 0.000 \\
\hline \hline LI-MP & 40.2482 & 43 & -2.757 & -6.849 & 62 & 0.000 \\
\hline \hline SNA & 82.36 & 82 & 0.362 & 0.724 & 62 & 0.472 \\
\hline \hline SNB & 79.49 & 80 & -0.057 & -0.121 & 62 & 0.904 \\
\hline ANB & 2.41 & 2 & 0.414 & 1.415 & 62 & 0.162 \\
\hline
\end{tabular}

To compares cephalometric values between the Kurdish and the Fastlicht's norm in 8 of the Iraqi Kurdish sample and the Iraqi (non- the 14 total parameters (Table 3). Two (U1Kurdish) data, a one-sample t-test was used. PP L1-MP) were not comparable due to Significant differences were found between different methods of measurements.

Table (3): Comparison of the cephalometric variables for the Iraqi Kurdish individuals versus Iraqi non-Kurdish individuals using a one-sample t-test

\begin{tabular}{|c||c||c||c||c|c||c||}
\hline Variable & $\begin{array}{c}\text { Iraqi } \\
\text { Kurdish }\end{array}$ & $\begin{array}{c}\text { Non- } \\
\text { Kurdish } \\
\text { Iraqi }\end{array}$ & Mean difference & T-test & $\begin{array}{c}\text { Degree of } \\
\text { freedom }\end{array}$ & p-value \\
\hline \hline UI-PP & 115.67 & 114.95 & 0.726 & 1.09 & 62 & 0.280 \\
\hline \hline UI-LI & 126.16 & 121.1 & 5.068 & 9.54 & 62 & 0.000 \\
\hline \hline LI-MP & 92.06 & 103.975 & -11.905 & -25.90 & 62 & 0.000 \\
\hline \hline MP-PP & 25.69 & 19.7 & 5.992 & 14.75 & 62 & 0.000 \\
\hline \hline Pt-Or/PtPNS & 78.64 & 78.75 & -0.107 & -0.29 & 62 & 0.776 \\
\hline \hline Pt-PNS/PP & 94.81 & 95.95 & -1.139 & -2.94 & 62 & 0.005 \\
\hline \hline Pt-Or/PP & 7.31 & 5.475 & 1.869 & 3.36 & 62 & 0.001 \\
\hline \hline N-Pog-UI & 4.72 & 0.676 & 4.051 & 14.96 & 62 & 0.000 \\
\hline \hline N-Pog-LI & 1.83 & 0.44 & -2.277 & -7.48 & 62 & 0.000 \\
\hline \hline UI-PP & 27.522 & & & & & \\
\hline \hline LI-MP & 40.2482 & & & & & \\
\hline \hline SNA & 82.36 & 83.75 & -1.388 & -2.78 & 62 & 0.007 \\
\hline \hline SNB & 79.49 & 80.65 & -0.707 & -1.49 & 62 & 0.140 \\
\hline ANB & 2.41 & 3.933 & -1.519 & -5.19 & 62 & 0.000 \\
\hline
\end{tabular}


Highly Significant differences $\mathrm{P}<0.001$ were parameters when comparing cephalometric found between the Kurdish and the values using a one-sample t-test Table(4). Caucasian norm in 10 of the 14 total

Table (4): Comparison of the cephalometric variables for the Iraqi Kurdish individuals versus average Caucasian data using a one-sample t-test

\begin{tabular}{|c||c||c||c||c||c||c||}
\hline Variable & Kurdish & Caucasian & $\begin{array}{c}\text { Mean } \\
\text { difference }\end{array}$ & $\begin{array}{r}\text { T-test } \\
\text { Degree of } \\
\text { freedom }\end{array}$ & P-value \\
\hline \hline UI-PP & 115.67 & 113 & 2.676 & 4.013 & 62 & 0.000 \\
\hline \hline UI-LI & 126.16 & 128 & -1.832 & -3.446 & 62 & 0.001 \\
\hline LI-MP & 92.06 & 93 & -0.930 & -2.023 & 62 & 0.047 \\
\hline \hline MP-PP & 25.69 & 26 & -0.308 & -0.758 & 62 & 0.451 \\
\hline \hline Pt-Or/PtPNS & 78.64 & 81 & -2.357 & -6.28 & 62 & 0.000 \\
\hline Pt-PNS/PP & 94.81 & 90 & 4.811 & 12.419 & 62 & 0.000 \\
\hline \hline Pt-Or/PP & 7.31 & 9 & -1.681 & -3.022 & 62 & 0.004 \\
\hline N-Pog-UI & 4.72 & 2 & 2.729 & 10.078 & 62 & 0.000 \\
\hline \hline N-Pog-LI & 1.83 & 1 & -2.837 & -9.319 & 62 & 0.000 \\
\hline \hline UI-PP & 27.522 & 34 & -6.478 & -17.405 & 62 & 0.000 \\
\hline \hline LI-MP & 40.2482 & 43 & -2.757 & -6.849 & 62 & 0.000 \\
\hline SNA & 82.36 & 82 & 0.362 & 0.724 & 62 & 0.472 \\
\hline \hline SNB & 79.49 & 80 & -0.057 & -0.121 & 62 & 0.904 \\
\hline \hline ANB & 2.41 & 2 & 0.414 & 1.415 & 62 & 0.162 \\
\hline
\end{tabular}

An independent t-test was used to compares cephalometric values between the Kurdish sample's male and female groups. The differences were found to be statistically significant $\mathrm{P}<0.05$ in three of the total 14 parameters, namely, LIMP, LIMPAng, and PtOrPP Table (5). 
The Application of Tetragon Analysis in A Sample of Kurdish Adult Population with Class I Occlusion:A Cephalometric Study

Table (5): Comparison of cephalometric values of (male) and (female)

\begin{tabular}{|c|c|c|c|c|c|c|c|c|c|c|}
\hline & & \multicolumn{7}{|c|}{ Independent T-Test } & & \\
\hline & & \multicolumn{2}{|c|}{$\begin{array}{l}\text { Levene's Test for Equality } \\
\text { of Variances }\end{array}$} & \multicolumn{5}{|c|}{ t-test for Equality of Means } & & \\
\hline & & \multirow{2}{*}{ F-value } & \multirow{2}{*}{ Significant } & \multirow{2}{*}{ t-value } & \multirow{2}{*}{$\begin{array}{l}\text { Degree of } \\
\text { freedom }\end{array}$} & \multirow{2}{*}{$\begin{array}{l}\text { Significant } \\
\text { (2tailed) }\end{array}$} & \multirow{2}{*}{\begin{tabular}{||c} 
Mean \\
Difference
\end{tabular}} & \multirow{2}{*}{\begin{tabular}{||c} 
Standard \\
Error \\
Difference
\end{tabular}} & \multicolumn{2}{|c|}{$\begin{array}{l}95 \% \text { Confidence Interval } \\
\text { of the Difference }\end{array}$} \\
\hline & & & & & & & & & Lower & Upper \\
\hline \multirow[b]{2}{*}{ NPogUI } & $\begin{array}{c}\text { Equal } \\
\text { variances } \\
\text { assumed }\end{array}$ & 2.177 & 0.145 & 0.883 & 61 & 0.381 & 0.48214 & 0.54584 & -0.60933 & 1.57362 \\
\hline & $\begin{array}{c}\text { Equal } \\
\text { variances } \\
\text { not } \\
\text { assumed }\end{array}$ & & & 0.904 & 60.987 & 0.369 & 0.48214 & 0.53309 & -0.58385 & 1.54813 \\
\hline \multirow{2}{*}{ NPogLI } & $\begin{array}{c}\text { Equal } \\
\text { variances } \\
\text { assumed }\end{array}$ & 4.517 & 0.038 & -0.708 & 61 & 0.481 & -0.43571 & 0.61500 & -1.66548 & 0.79405 \\
\hline & $\begin{array}{c}\text { Equal } \\
\text { variances } \\
\text { not } \\
\text { assumed }\end{array}$ & & & -0.734 & 60.390 & 0.466 & -0.43571 & 0.59330 & -1.62234 & 0.75091 \\
\hline \multirow[b]{2}{*}{ UIPP } & $\begin{array}{c}\text { Equal } \\
\text { variances } \\
\text { assumed }\end{array}$ & 1.600 & 0.211 & 0.907 & 61 & 0.368 & 0.68000 & 0.75007 & -0.81987 & 2.17987 \\
\hline & $\begin{array}{c}\text { Equal } \\
\text { variances } \\
\text { not } \\
\text { assumed }\end{array}$ & & & 0.936 & 60.790 & 0.353 & 0.68000 & 0.72682 & -0.77347 & 2.13347 \\
\hline \multirow[b]{2}{*}{ LIMP } & $\begin{array}{c}\text { Equal } \\
\text { variances } \\
\text { assumed }\end{array}$ & 0.502 & 0.481 & 3.318 & 61 & 0.002 & 2.49429 & 0.75172 & 0.99114 & 3.99744 \\
\hline & $\begin{array}{c}\text { Equal } \\
\text { variances } \\
\text { not } \\
\text { assumed }\end{array}$ & & & 3.258 & 53.093 & 0.002 & 2.49429 & 0.76563 & 0.95869 & 4.02988 \\
\hline \multirow[b]{2}{*}{ UIPPAng } & $\begin{array}{c}\text { Equal } \\
\text { variances } \\
\text { assumed }\end{array}$ & 0.005 & 0.944 & -0.564 & 61 & 0.575 & -0.76071 & 1.34958 & -3.45937 & 1.93794 \\
\hline & $\begin{array}{c}\text { Equal } \\
\text { variances } \\
\text { not } \\
\text { assumed }\end{array}$ & & & -0.561 & 56.708 & 0.577 & -0.76071 & 1.35696 & -3.47828 & 1.95685 \\
\hline
\end{tabular}


The Application of Tetragon Analysis in A Sample of Kurdish Adult Population with Class I Occlusion:A Cephalometric Study

\begin{tabular}{|c|c|c|c|c|c|c|c|c|c|c|}
\hline \multirow[b]{2}{*}{ UILIAng } & $\begin{array}{c}\text { Equal } \\
\text { variances } \\
\text { assumed }\end{array}$ & 0.224 & 0.638 & -0.019 & 61 & 0.985 & -0.02000 & 1.07835 & -2.17630 & 2.13630 \\
\hline & $\begin{array}{c}\text { Equal } \\
\text { variances } \\
\text { not } \\
\text { assumed }\end{array}$ & & & -0.018 & 51.895 & 0.986 & -0.02000 & 1.10260 & -2.23264 & 2.19264 \\
\hline \multirow[b]{2}{*}{$\begin{array}{l}\text { LIMPAn } \\
\mathrm{g}\end{array}$} & $\begin{array}{c}\text { Equal } \\
\text { variances } \\
\text { assumed }\end{array}$ & 0.028 & 0.869 & 2.132 & 61 & 0.037 & 1.91857 & 0.89981 & 0.11929 & 3.71785 \\
\hline & $\begin{array}{c}\text { Equal } \\
\text { variances } \\
\text { not } \\
\text { assumed }\end{array}$ & & & 2.126 & 57.321 & 0.038 & 1.91857 & 0.90248 & 0.11161 & 3.72553 \\
\hline \multirow{2}{*}{ MPPP } & $\begin{array}{c}\text { Equal } \\
\text { variances } \\
\text { assumed }\end{array}$ & 0.130 & 0.720 & -1.093 & 61 & 0.279 & -0.89214 & 0.81649 & -2.52482 & 0.74053 \\
\hline & $\begin{array}{c}\text { Equal } \\
\text { variances } \\
\text { not } \\
\text { assumed }\end{array}$ & & & -1.099 & 59.143 & 0.276 & -0.89214 & 0.81188 & -2.51663 & 0.73234 \\
\hline \multirow{2}{*}{ UpperPt } & $\begin{array}{c}\text { Equal } \\
\text { variances } \\
\text { assumed }\end{array}$ & 0.964 & 0.330 & -0.025 & 61 & 0.980 & -0.01929 & 0.76149 & -1.54198 & 1.50341 \\
\hline & $\begin{array}{c}\text { Equal } \\
\text { variances } \\
\text { not } \\
\text { assumed }\end{array}$ & & & -0.026 & 59.654 & 0.980 & -0.01929 & 0.75490 & -1.52950 & 1.49093 \\
\hline \multirow{2}{*}{ LowerPt } & $\begin{array}{c}\text { Equal } \\
\text { variances } \\
\text { assumed }\end{array}$ & 0.698 & 0.407 & 0.738 & 61 & 0.463 & 0.57786 & 0.78251 & -0.98687 & 2.14259 \\
\hline & $\begin{array}{c}\text { Equal } \\
\text { variances } \\
\text { not } \\
\text { assumed }\end{array}$ & & & 0.752 & 60.748 & 0.455 & 0.57786 & 0.76842 & -0.95882 & 2.11453 \\
\hline \multirow[b]{2}{*}{ PtOrPP } & $\begin{array}{c}\text { Equal } \\
\text { variances } \\
\text { assumed }\end{array}$ & 0.362 & 0.549 & -3.005 & 61 & 0.004 & -3.16500 & 1.05317 & -5.27094 & -1.05906 \\
\hline & $\begin{array}{c}\text { Equal } \\
\text { variances } \\
\text { not } \\
\text { assumed }\end{array}$ & & & -2.999 & 57.509 & 0.004 & -3.16500 & 1.05545 & -5.27810 & -1.05190 \\
\hline SNA & $\begin{array}{c}\text { Equal } \\
\text { variances } \\
\text { assumed }\end{array}$ & 1.080 & 0.303 & 0.583 & 61 & 0.562 & 0.58929 & 1.01084 & -1.43201 & 2.61058 \\
\hline
\end{tabular}




\begin{tabular}{|c|c|c|c|c|c|c|c|c|c|c|}
\hline & $\begin{array}{c}\text { Equal } \\
\text { variances } \\
\text { not } \\
\text { assumed }\end{array}$ & & & 0.568 & 50.925 & 0.572 & 0.58929 & 1.03677 & -1.49218 & 2.67075 \\
\hline \multirow[b]{2}{*}{ SNB } & $\begin{array}{c}\text { Equal } \\
\text { variances } \\
\text { assumed }\end{array}$ & 0.580 & 0.449 & 0.665 & 61 & 0.508 & 0.63643 & 0.95678 & -1.27676 & 2.54962 \\
\hline & $\begin{array}{c}\text { Equal } \\
\text { variances } \\
\text { not } \\
\text { assumed }\end{array}$ & & & 0.656 & 54.388 & 0.515 & 0.63643 & 0.97024 & -1.30846 & 2.58132 \\
\hline \multirow[b]{2}{*}{ ANB } & $\begin{array}{c}\text { Equal } \\
\text { variances } \\
\text { assumed }\end{array}$ & 0.020 & 0.888 & -0.087 & 61 & 0.931 & -0.05143 & 0.59403 & -1.23927 & 1.13641 \\
\hline & $\begin{array}{c}\text { Equal } \\
\text { variances } \\
\text { not } \\
\text { assumed }\end{array}$ & & & -0.086 & 55.722 & 0.932 & -0.05143 & 0.59953 & -1.25256 & 1.14971 \\
\hline
\end{tabular}

\section{Discussion}

The Tetragon and the Trigon provide a clear picture of the position of the maxillodentomandibular structures within the craniofacial complex. This visual cephalometric analysis can be a useful diagnostic tool for treatment planning, surgical preparation, and evaluation of growth, treatment progress, and posttreatment results.

In addition to conventional cephalometric measurements such as SNA, SNB, and ANB, the Tetragon is able to show whether the malocclusion problem lies in the mandible, maxilla, or both as well. The Tetragon's analysis enables the operator to identify the need for suitable tooth movement (intrusion, extrusion, and retraction) as it represents the axial inclinations of the maxillary and mandibular central incisors and their positions in the oral cavity.

This study aimed to set the normal values of the visual cephalometric analysis, the Tetragon analysis, for a sample of Iraqi
Kurdish people. As a result, malocclusion categories could be described using the concluded analysis from Iraqi Kurdish individuals accurately and enables clinicians to establish a treatment plan as per the ethnic variation.

\section{Tetragon}

Compared to Fastlich, more proclination of the upper and lower incisor were found in the Kurdish population reflected by increased upper incisors to palatal plane angle, increased lower incisors to mandibular plane angle, and decreased inter-incisal angle. The same results were reported by Nanda et al. and Valiathan et al. [6,11]. Interestingly, the current study showed a reduction in the mandibular plane's angulation to the Kurdish population's palatal plane. This indicates the tendency of upper and lower jaw bases to converge, lower anterior facial height to decrease, and horizontal growth pattern. Compared to Iraqi data, the LI-MP is decreased, MP-PP is increased, and the inter- 
incisal angle is increased than that of the Iraqi population. These differences can be explained in part by the difference in ethnic background. This study shows a statistically significant increase of upper incisor to palatal plane compared to average Caucasian data while other data of the Tetragon did not differ significantly than that of Caucasian sample.

\section{Trigon}

This study reveals that there is an increase in the angulation of Pt-PNS/PP and a decrease in the angulation of Pt-Or/ PP \& PtOr/Pt-PNS when comparing with Fastlich's. All these differences are statistically significant. Compared to the Iraqi data, there was an insignificant difference in $\mathrm{Pt}-\mathrm{Or} / \mathrm{Pt}$ PNS; however, there is a decrease in the angulation of Pt-PNS/PP and an increase in the angulation of $\mathrm{Pt}-\mathrm{Or} / \mathrm{PP}$, which are both statistically significant differences.

The different ethnic backgrounds can explain these differences again[14]; the Iraqi data is collected from Baghdad University, where most of the students are expected to be of Arabic ethnicity, although this detail is not mentioned in that study. When compared to average Caucasian data, Pt-Or/Pt-PNS \& PtOr/PP were statistically higher. In contrast, Pt-PNS/PP were statically lower[9]. Our data indicate a clockwise rotation of the palatal plane, the Trigon in this sample is rotated clockwise compared to Fastlich's sample and average Caucasian [9], and that is represented by the increase in Pt- PNS/PP angle. This was in agreement with Ahmed [14], Prakash et al[15], and Gupta et al[16]. Other angles, SNA, SNB \& ANB, did not show significant differences compared to Fastlich and Average while comparing to Iraqi SNA, \&
ANB were significantly different. Linear measurement was statistically different when compared to our Kurdish data to Fastlich and Average Caucasian data. In the current study, the differences between males and females were statistically significant in three of the total 14 parameters: LIMP, LIMPAng, and PtOrPP. Variations in the cephalometric values that deal with the head and face measurements of alive and dead bodies are regarded as one of the disciplines of anthropometry. The existing variations between the Kurdish sample and others can be attributed to many factors such as ethnic background, environmental factors, nutrition, heredity, and socio-economic status.

\section{Conclusions}

This study showed various differences when comparing finding with the study by Fastlicht and other subsequent studies. Accordingly, patient cephalometric data is mandatory to be compared with the standards of similar ethnic backgrounds for an accurate diagnostic evaluation.

\section{Recommendations}

This study's recommendation is to utilize this study's standards when applying tetragon analysis to acquire more accurate results concerning Iraqi Kurdish people.

Source of funding: The author did not receive financial support for this research and publication of this article

Ethical clearance: This study was granted ethical approval from the Ethical Committee of the College of Dentistry at Hawler Medical University

Conflict of interest: The author declares that there is no conflict of interest regarding the publication of this article. 


\section{References}

[1]Park IC, Bowman D, Klapper L. A cephalometric study of Korean adults. American journal of orthodontics and dentofacial orthopedics : official publication of the American Association of Orthodontists, its constituent societies, and the American Board of Orthodontics. 1989;96(1):54-9.

https://doi.org/10.1016/0889-5406(89)90229$\underline{1}$

[2]Naranjilla MA, Rudzki-Janson I. Cephalometric features of Filipinos with Angle Class I occlusion according to the Munich analysis. The Angle orthodontist. 2005;75(1):63-8.

https://doi.org/10.1043/0003-

3219(2005)075<0063:CFOFWA >2.0.CO;2

[3]Richardson ER. Racial differences in dimensional traits of the human face. The Angle orthodontist. 1980;50(4):301-11. https://doi.org/10.1043/0003-

3219(1980)050<0301:RDIDTO >2.0.CO;2

[4]Iyer VS, Lutz W. Cephalometric comparison of Indian and English facial profiles. American journal of physical anthropology.1966;24(1):117-26.

https://doi.org/10.1002/ajpa.1330240111

[5]Miura $\mathrm{F}$, Inoue $\mathrm{N}$, Suzuki $\mathrm{K}$. CEPHALOMETRIC STANDARDS FOR JAPANESE ACCORDING TO THE STEINER ANALYSIS. American journal of orthodontics.1965;51:288-95. https://doi.org/10.1016/0002-9416(65)90103$\underline{X}$

[6]Nanda R, Nanda RS. Cephalometric study of the dentofacial complex of North Indians. The Angle Orthodontist. 1969;39(1):22-8. https://doi.org/10.1043/00033219(1969)039< 0022:CSOTDC>2.0.CO;2
[7] Karaca Bozdag Z, Kurkcuoglu A, Ustdal A, Cam Y, Oğuz Ö. An Assessment of Gender Difference in Visual Cephalometric Analysis Applied to Class I Individuals: A Preliminary Study. Eastern Journal of Medicine.2019;24:1-7. https://doi.org/10.5505/ejm.2019.40570 [8]Ajayi EO. Cephalometric norms of Nigerian children. American journal of orthodontics and dentofacial orthopedics : official publication of the American Association of Orthodontists, its constituent societies, and the American Board of Orthodontics.2005;128(5):653-6.

https://doi.org/10.1016/j.ajodo.2005.07.002

[9]Fastlicht J. Tetragon, a visual cephalometric analysis. J Clin Orthod. 2000(33):353-60.

[10]Rakosi T. An atlas and manual of cephalometric radiography: Lea \& Febiger; 1982.

[11]Valiathan A. Racial comparison of dentofacial cephalometric norms using Downs' analysis. Journal of the Indian Dental Association. 1975;47(11):461-4.

[12]Arunkumar KV, Reddy VV, Tauro DP. Establishment of Cephalometric Norms for the South Indian (Karnataka) Population Based on Burstone's Analysis. Journal of Maxillofacial and Oral Surgery. 2010;9(2):127-33. https://doi.org/10.1007/s12663-010-0039-2 [13]Valiathan A. Tweeds analysis applied to Indian adults. JIDA. 1976;48:215-7. [14] Ahmed AS. Cephalometric evaluation of a sample of Iraqi adults with normal occlusion using tetragon analysis. Journal of Baghdad College of Dentistry. 2014;26:1636. https://doi.org/10.12816/0015158 
[15]Prakash AT, Shetty KS, Sudhakar P. Dental and Skeletal Characteristics of Individuals with Normal, Class II and Class III Occulsions - A Cephalometric Evaluation using Tetragon Analysis. Journal of Indian Orthodontic Society. 2010;44(4):63-71. https://doi.org/10.1177/0974909820100412 [16]Gupta N, Gupta G, Umasankar K, Sundari KK. Establishing the Cephalometric Values for Tetragon Analysis in Patients with Class I Occlusion: A Cephalometric Study. The Journal of Contemporary Dental practice.2016;17(7):597-600.

https://doi.org/10.5005/jp-journals-10024$\underline{1896}$ 